\section{Pengembangan Media Pembelajaran \\ Berbasis E-Learning Portable Moodle Materi Sistem Koordinasi Untuk SMA Kelas XI IPA}

\author{
Nurlinah \\ Adnan \\ Muhiddin P.
}

\begin{abstract}
Abstrak. Penelitian ini bertujuan untuk mengetahui kevalidan dan kepraktisan media pembelajaran portable moodle (poodle) dalam pembelajaran biologi. Penelitian ini merupakan penelitian pengembangan dengan model 4D. Subjek penelitian ini adalah siswa kelas XI IPA 1 dan XI IPA 2 SMA Negeri 20 Pangkajene, Pangkep dan guru mata pelajaran Biologi. Penelitian ini dilaksanakan selama 4 kali pertemuan untuk ujicoba media oleh peneliti dan guru mata pelajaran. Teknik pengumpulan adalah melakukan validasi terlebih dahulu kepada validator ahli, lalu membagikan angket respon guru mata pelajaran dan respon siswa untuk menguji kepraktisan media yang telah dibuat. Hasil validasi ahli menunjukkan bahwa produk pengembangan media memiliki kriteria valid berdasarkan penilaian oleh ahli materi sebesar 4,3 dan ahli media sebesar 4,6. Uji lapangan dilakukan kepada siswa SMAN 20 Pangkejene dan guru mata pelajaran biologi sebagai pengguna produk media, dan diperoleh kriteria berdasarkan perolehan skor prosentase penilaian pada masing-masing uji coba sebesar 79,62\% untuk respon siswa dan 90\% untukl respon guru mata pelajaran. Berdasarkan analisis data pada penelitian ini diperolehkesimpulan bahwa hasil pengembangan media berbasis poodle diperoleh kriteria valid dan praktis untuk digunakan dalam pembelajaran biologi.
\end{abstract}

Kata Kunci: media, portable, moodle, valid, praktis.

\section{Pendahuluan}

Belajar mengajar pada dasarnya merupakan proses interaksi edukatif antara guru dan siswa. Tujuan dari interaksi edukatif tersebut meliputi tiga aspek, yakni aspek kognitif, afektif dan psikomotorik. Untuk mencapai tujuan secara baik, diperlukan peran maksimal dari seorang guru, baik dalam penyampai materi, penggunaan metode, pengelolaan kelas dan sebagainya. Sistem koordinasiain itu, diharapkan kepada guru untuk lebih kreatif untuk melakukan kegiatan pendukung pembelajaran di dalam kelas, salah satu kegiatan pendukung yang dimaksud adalah dengan menggunakan media pembelajaran.

Fungsi media dalam kegiatan pembelajaran tidak hanya sekedar alat peraga bagi guru, melainkan pembawa pesanpesan informasi dan pesan-pesan pembelajaran yang dibutuhkan peserta didik. Dalam beberapa tahun terakhir, pemanfaatan ICT (Information and Communication Technology) dalam dunia pendidikan sudah mulai memasyarakat, mulai dari jenjang pendidikan dasar, menengah, sampai ke perguruan tinggi, meskipun variasi dan fokus pemanfaatannya berbeda-beda pada masingmasing institusi. Kehadiran dan kemajuan ICT di era komunikasi global dewasa ini telah memberikan peluang dan perluasan interaksi antara guru dan siswa, antar siswa, antara siswa dan sumber-sumber belajar dapat terjadi kapan saja dan di mana saja tanpa dibatasi oleh ruang dan waktu.

Pengembangan e-learning bertujuan untuk mendukung

\section{Biology Teaching and Learning}

p-ISSN 2621 - 5527

e-ISSN 2621 - 5535

Abstract. This study aims to determine the validity and practicality of moodle (poodle) portable learning media in biology learning. This research is a development research with $4 D$ models. The subjects of this study were students of class XI IPA 1 and XI IPA 2 Senior High School of Pangkajene 20, Pangkep and Biology teachers. This study was conducted for 4 meetings for media trials by researchers and Biology teachers. The collection technique was to validate the expert validator first, then share the questionnaire responses of the teachers and student responses to test the practicality of the media that has been made. The results of expert validation showed that media development products have valid criteria based on assessment by material experts at 4.3 and media experts at 4.6. Field tests were carried out for students of Senior High School of

Pangkajene 20 and biology teachers as the users of media products, and obtained criteria based on the acquisition of scores percentage of assessments in each trial amounted to $79.62 \%$ for student responses and $90 \%$ for teacher responses. Based on the data analysis in this study, it was concluded that the results of the development of poodle-based media obtained valid and practical criteria for use in biology learning.

Keywords: media, portable, moodle, valid, practical.

Nurlinah

Universitas Negeri Makassar Indonesia

Adnan

Universitas Negeri Makassar Indonesia

Muhiddin P.

Universitas Negeri Makassar Indonesia 
penyelenggaraan pendidikan, sehingga sekolah dapat menyediakan layanan informasi yang lebih baik kepada komunitasnya, baik di dalam maupun di luar melalui internet. Layanan pendidikan lain yang bisa dilaksanakan melalui sarana internet yaitu dengan menyediakan materi pelajaran secara online yang dapat diakses oleh siapa saja yang membutuhkan. Seiring dengan kebutuhan akan metode dan konsep pembelajaran yang lebih efektif dan efisien, pemanfaatan teknologi informasi untuk pendidikan menjadi tidak terelakkan lagi. Konsep yang kemudian terkenal dengan sebutan $e$ learning ini membawa pengaruh terjadinya proses transformasi pendidikan konvensional ke dalam bentuk digital, baik secara isi (contents) maupun sistemnya.

E-learning memberikan harapan baru sebagai alternatif solusi atas sebagian besar permasalahan pendidikan di Indonesia, dengan fungsi yang dapat disesuikan dengan kebutuhan, baik sebagai suplemen (tambahan), komplemen (pelengkap), ataupun substitusi (pengganti) atas kegiatan pembelajaran di dalam kelas yang sistem koordinasiama ini digunakan.

LMS yang berbasis Open Source, MOODLE (Modular Object-Oriented Dynamic Learning Environment) diakui sebagai salah satu LMS yang terbaik dan terlengkap dengan total sebanyak 38.896 situs yang telah menerapkannya, 16.927 .590 pengguna, dan 1.713 .438 materi berdasarkan statistik bulan Januari 2008 (Inixindojogja, 2008). Moodle adalah sebuah nama untuk sebuah program aplikasi yang dapat merubah sebuah media pembelajaran ke dalam bentuk web. Aplikasi ini memungkinkan siswa untuk masuk ke dalam "ruang kelas digital" untuk mengakses materi pembelajaran. Dengan menggunakan moodle, dapat dibuat materi pembelajaran, kuis, jurnal elektronik dan lain-lain. Saat ini pun tersedia layanan aplikasi moodle yang dapat digunakan secara offline, jadi siswa tidak perlu terkoneksi internet untuk menggunakan aplikasi pembelajaran ini.

\section{Fokus Penelitian}

Berdasarkan berbagai hat tersebut, maka salah satu hasil skripsi ini adalah mengembangkan LMS yang berbasis Open Source, MOODLE (Modular Object-Oriented Dynamic Learning Environment) yang bersifat portable. merupakan sebuah paket software opensource yang dapat menjalankan moodle dan konten di dalamnya (course, resource, quiz dan seterusnya) pada PC secara offline. Poodle dapat diinstal pada PC desktop/Laptop pribadi, dan juga dapat diinstal pada flashdisk/CD-ROM/Memory Card/Harddisk. Guru dapat membuat konten course (resource / activity secara offline), untuk selanjutnya dipelajari oleh siswa. Siswa juga dapat mengerjakan aktivitas kuis secara offline, kemudian melakukan self- assessment secara offline pula. Karena bersifat offline, maka Poodle tidak secara otomatis terkoneksi dengan situs resmi moodle. Meski begitu, semua keperluan anda terkait moodle telah tersedia pada software ini.

\section{Metode Penelitian}

\section{Jenis Penelitian}

Model penelitian yang digunakan adalah penelitian pengembangan atau Research and Development (R \& D). Pengembangan yang digunakan dalam pengembangan media pembelajaran berbasis poodle pada mata pelajaran biologi adalah model pengembangan $4 \mathrm{D}$ (Four D). Dalam model ini penilaian dan pengulangan perlu dijalankan dalam setiap tahap.

\section{Instrumen Penelitian}

Instrumen yang digunakan dalam penelitian ini adalah instrumen validasi, respon guru dan respon siswa. Data yang telah dikumpulkan dengan menggunakan instrumen-instrumen selanjutnya dianalisis secara kuantitatif dan diarahkan untuk mengarahkan kevalidan isi media pembelajaran. 


\section{Analisis Data}

Analisis data kevalidan media pembelajaran meliputi analisis materi, perangkat pembelajaran dan keseluruhan konstruksi software. Analisis kevalidan materi, dan perangkat pembelajaran berdasarkan saran yang diberikan oleh tim ahli berupa perbaikan bahasa, petunjuk penggunaan, ataupun hal lainnya mencakup isi media.

\section{Hasil Penelitian}

Hasil validasi instrumen media dan materi oleh validator ahli.

\section{Tabel 1. Skala Persentase Penilaian Materi Ke Dua Validator}

\begin{tabular}{|c|c|c|c|c|c|}
\hline \multirow{2}{*}{ No } & \multirow{2}{*}{ Kriteria } & \multicolumn{2}{|c|}{ Persentase } & \multirow{2}{*}{$\begin{array}{c}\text { Rata-rata } \\
\% \\
\end{array}$} & \multirow{2}{*}{ Keterangan } \\
\hline & & I & II & & \\
\hline 1 & Aspek tujuan pembelajaran & $100 \%$ & $100 \%$ & $100 \%$ & Baik / Valid \\
\hline 2 & Aspek Isi/konten & $80 \%$ & $80 \%$ & $80 \%$ & Baik / Valid \\
\hline 3 & Aspek Konsep Pembelajaran & $100 \%$ & $80 \%$ & $90 \%$ & Baik / Valid \\
\hline 4 & Aspek pengorganisasian Materi & $80 \%$ & $92 \%$ & $86 \%$ & Baik / Valid \\
\hline 5 & Aspek konsep teknis & $100 \%$ & $100 \%$ & $100 \%$ & Baik / Valid \\
\hline 6 & Konsep desain interaksi & $90 \%$ & $100 \%$ & $95 \%$ & Baik / Valid \\
\hline 7 & Konsep media & $80 \%$ & $80 \%$ & $80 \%$ & Baik / Valid \\
\hline 8 & Konsep komunikasi & $80 \%$ & $90 \%$ & $85 \%$ & Baik / Valid \\
\hline 9 & Tes dan evaluasi & $90 \%$ & $80 \%$ & $85 \%$ & Baik / Valid \\
\hline 10 & Rekaman aktivitas & $80 \%$ & $100 \%$ & $90 \%$ & Baik / Valid \\
\hline 11 & Administrasi & $80 \%$ & $90 \%$ & $84 \%$ & Baik / Valid \\
\hline 12 & Aktivitas & $80 \%$ & $100 \%$ & $90 \%$ & Baik / Valid \\
\hline 13 & Review tingkat kompetensi & $80 \%$ & $100 \%$ & $90 \%$ & Baik / Valid \\
\hline \multicolumn{4}{|c|}{ Rata-rata Keseluruhan } & $88,84 \%$ & Baik / Valid \\
\hline
\end{tabular}

Berdasarkan hasil validasi oleh kedua validator materi, maka ditentukan skala persentase penilaian materi, maka untuk rata-rata keseluruhan persentase mencapai 88,84\% dengan rentang penilaian $70 \%-90 \%$ sehingga hasil validasi materi dinyatakan baik/valid. Hal ini menunjukkan bahwa keseluruhan komponen yang disajikan dalam media e-learning poodle layak untuk digunakan dalam proses belajar mengajar dan sebagai media pendukung pembelajaran, baik dari desain/struktur maupun dari segi bahasa.

\section{Hasil Respon Guru \& Siswa Terhadap Media Pembelajaran}

\section{Tabel 2. Hasil Analisis Data Respon Guru \& Siswa}

\begin{tabular}{|l|l|l|}
\hline Rerata Guru & 4,5 & Positif \\
\hline Rerata Siswa & 4,03 & Positif \\
\hline
\end{tabular}

Berdasarkaan Tabel 4.11 dapat dilihat bahwa hasil penilaian guru terhadap media pembelajaran poodle untuk masing-masing aspek berada pada kategori praktis dan sangat praktis. Sementara untuk rata-rata penilaian secara keseluruhan yakni skor 4,5 dengan kategori "praktis". Persentase hasil respon guru terhadap media pembelajaran poodle adalah sangat positif dengan rentang nilai $85 \% \leq$ RG. Menurut Hobri (2009) media pembelajaran e-learning dikatakan praktis jika guru menyatakan bahwa media memudahkan siswa dalam belajar dan bersifat komunikatif dan interaktif. Kepraktisan penggunaan media juga harus didukung oleh ketersediaan sarana dan prasarana di lingkungan pembelajaran.

Berdasarkan perhitungan respon siswa terhadap penerapan media pembelajaran poodle rerata 4,03 yakni kategori praktis. 


\section{Pembahasan}

Materi yang bersifat prosedural merupakan materi yang sulit dijelaskan oleh guru. Salah satu materi prosedural pada pokok bahasan sistem koordinasi adalah mekanisme jalannya impuls pada sinaps. Mekanisme jalannya impuls adalah pengetahuan proses, karena berupa proses untuk itu diperlukan visualisasi yang jelas. Visualisasi dengan bantuan multimedia memudahkan guru menyampaikan materi. Penggunaan visualisasi berupa gambar, animasi, dan video juga memudahkan siswa dalam memahami materi.

Produk yang dihasilkan dalam penelitian ini berupa pembelajaran biologi berbasis poodle yang membahas materi sistem koordinasi untuk SMA. Pembelajaran biologi didesain dengan penggunaan portable moodle yang disingkat poodle sebagai media untuk mengajar guru. Diharapkan dengan pembelajaran berbasis poodle dapat mengatasi keterbatasan ruang dan waktu. Pembelajaran biologi berbasis poodle merupakan pengembangan pembelajaran yang dikembangkan dengan penambahan konten multimedia (audio-visual) berupa animasi, video, gambar, teks serta kuis.

Hasil penilaian validator menyebutkan bahwa secara umum pembelajaran biologi berbasis poodle yang dikembangkan menarik, materi sudah memenuhi standar kompetensi, kompetensi dasar dan indikator pembelajaran serta langkah-langkah pembelajaran yang digunakan sudah sesuai dengan materi. Konsep yang disampaikan melalui poodle dinilai sudah sesuai dengan konsep yang benar.

Pengembangan pembelajaran berbasis poodle dinilai validator tepat untuk dikembangkan pada materi sistem koordinasi karena dapat memotivasi siswa untuk belajar dan lebih aktif di kelas. Menurut LeDuff, R. (2004), teknologi Multimedia Presentations dapat meningkatkan motivasi, meningkatkan prestasi siswa, dan memungkinkan untuk interaksi yang lebih besar dengan materi pelajaran. Hasil validator pembelajaran memberikan skor rata-rata 4.3 yakni kategori valid. Hasil ini didapatkan setelah melakukan revisi beberapa kali dan perbaikan dan penambahan fitur-fitur yang bervariasi pada media yang dikembangkan.

Hasil yang ditemukan dilapangan adalah bahwa rerata respon siswa adalah 4,03 termasuk kategori praktis meskipun cukup jauh dari ekspektasi peniliti, hal ini dikarenakan oleh kurangnya sebagian perhatian siswa terhadap guru, serta terkendala pula dalam proses instalasi portable moodle, karena ternyata dalam pelaksanaanya, terdapat laptop siswa yang tidak bisa mengoperasikan aplikasi ini karena keterbatasan aplikasi pendukung di dalamnya, sehingga hal inilah yang menyebabkan respon siswa positif agak kurang terhadap media yang dikembangkan.

Selanjutnya adalah uji kepraktisan, indikator kepraktisan pembelajaran biologi berbasis poodle selain dilihat dari respon siswa, juga dilihat dari hasil analisis respon guru mata pelajaran. Berdasarkan hasil respon guru terhadap pembelajaran biologi berbasis poodle diperoleh rerata respon guru terhadap penerapan pembelajaran berbasis poodle mencapai skor persentase $90 \%$ atau 4,8 kategori sangat praktis, meskipun dengan berbagai kekurangan misalnya, guru harus senantiasa mengecek aktivitas siswa pada akun mereka maing-masing sehingga cukup membutuhkan waktu yang lama. Menurut Yamasari (2010), media pembelajaran berbantuan komputer dikatakan praktis jika validator menyatakan bahwa media pembelajaran berbantuan komputer tersebut praktis digunakan dalam pembelajaran. Menurut Hobri (2009), media dikatakan praktis jika secara nyata di lapangan media yang dikembangkan dapat diterapkan dalam proses pembelajaran.

Berdasarkan hasil respon siswa terhadap pembelajaran biologi berbasis poodle termasuk dalam kategori positif dengan rata-rata keseluruhan persentase yaitu 79,62 \% dengan melihat kategori kepraktisan $70 \% \leq \mathrm{RS}<85 \%$, sehingga dapat dinyatakan bahwa media pembelajaran poodle bersifat praktis jika ditinjau dari respon siswa. Penelitian yang dilakukan oleh Chaudhari (2013) menyimpulkan bahwa pembelajaran berbantuan komputer sangat efektif dalam pembelajaran biologi. Lowe (2004) menemukan bahwa pembelajaran berbasis komputer lebih memberikan dampak positif pada siswa dibandingkan dengan pembelajaran di kelas yang bersifat tradisional. 
Pengembangan Media Pembelajaran Berbasis E-Learning Portable Moddle

Materi Sistem Koordinasi Untuk SMA Kelas XI IPA

(hlm. 160-166)

p-ISSN 2621-5527

e-ISSN 2621-5535

Multimedia dalam media pembelajaran berbasis poodle menggabungkan animasi, teks, gambar dan soal. Waith, Easton dan Anderson (2000, dalam Caspi, 2005) berpendapat bahwa belajar dengan narasi video dapat menciptakan keefektivan dalam belajar. Selain itu narasi dan video juga dapat meningkatkan motivasi belajar siswa. Fengfeng (2006) menyatakan bahwa animasi menyenangkan digunakan dalam pembelajaran. Gambar diam maupun bergerak merupakan inti dari multimedia yang dapat digunakan untuk meningkatkan materi pembelajaran berbasis komputer dalam proses belajar (Williams, 1995).

Meskipun siswa merasa membutuhkan waktu persiapan lebih lama untuk belajar. Belajar dengan poodle membuat siswa semakin termotivasi meskipun poodle memiliki beberapa kesulitan dalam penggunaannya. Misalnya ketika menggunakan poodle maka harus melalui proses instalasi, dan ternyata tidak semua laptop mampu mengakses aplikasi ini. Serta kekurangan yang lain adalah guru harus mengecek satu per satu tugas yang di berikan kepada siswa, dan ini membutuhkan banyak waktu untuk penilaian secara manual.

\section{Kesimpulan}

Berdasarkan hasil penelitian dari analisis data dan pembahasan, maka dapat disimpulkan bahwa media pembelajaran poodle valid, praktis dan efektif untuk siswa kelas XI SMA.

\section{Referensi}

American Society for Training and Development. (2007). ISD Model. United States of America.

Anonim. (2000). Pengantar Internet. Semarang: STMIK Dian dan Lintang Nuswantoro.

Anung H, \& Abubakar A. (2003). Virtual Learning / Virual Classroom Sebagai Model Pendidikan Jarak Jauh: Konsep dan Penerapnnya, Jakarta, Jurnal Teknodik Depdiknas. 13 (VII)

Anwar, M. (2000) Internet: Peluang dan Tantangan Pendidikan Nasional, Jakarta, Jurnal Teknodik Depdiknas.

Anwas, M (2003), Model Inovasi E-Lerning Dalam Meningkatkan Mutu Pendidikan. Jakarta. Jurnal Teknodik Depdiknas. 2 (VII).

Arsyad, A. (2003). Media Pembelajaran. PT. Raja Cerapinidi Persada. Jakarta.

Caspi, A., Gorsky. P., \& Privman. M. (2005). Viewing Comphrehension: Students Learning Preferences and Strategies when styding from video. Iinstructional Science. 33, 31-47_Springer 2005 DOI: $10.1007 / \mathrm{s} / 11251-004-2576$

Cisco, (2001), E-learning: Combines Communication, Education, Information, and Training. http://www.cisco.com/warp/public/10/wwtraining/elearning.

Darwis, M. (2007). Model Pembelajaran Matematika yang Melibatkan Kecerdasan Emosional. Disertasi, Program Pascasarjana Program Studi Pendidikan Matematika Universitas Negeri Surabaya. Tidak Diterbitkan.

Fengfeng., Lin, H., \& Ching Y.H. (2006). Effect of Animation on Multi-Level Learning Outcomes for Learners with Different Characteristics: A Meta Analytic Assesment and Interpretation. Journal of Visual Literacy. 26 (1), 15-40

Gerlach, V.G. \& Ely, D.P. (1971). Teaching and Media. A Systematic Approach. ENglewood Cliffs: Prentice-Hall, Inc. 
Gustafson, K. \& Branch, R. (1997) Revisioning Models of Instructional Development. Educational Technology Research and Development. 45 (3), 73-89.

Hardjito. (2002). Internet Untuk Pembelajaran. http://www.pustekkom.go.id (diakses pada tanggal 24 Februari 2017).

Hobri. (2009). Metodologi Penelitian dan Pengembangan (Developmental Research) (Aplikasi pada penelitian pendidikan matematika). Jember: FKIP Universitas Jember

Khan, B.H. (2001). Web Based Learning. http://www.bookstoread.com/bestsistem koordinasiler /khan/wbl.html (diakses pada tanggal 14 Maret 2017).

Lowe, J.S., (2004). A Theory of Effective Computer Based Instruction for Adults. Louisiana. University of Lousiana.

Milaningrum, Elisabeth, Tarjana, Sumardi. (2013). Amiroh. 2012. Poodle-Portable Moodle: Solusi ELearning Murah. http://amiroh.web.id/membangun-moodle-2-portable-solusi-e-learningmurah/ (diakses pada tanggal 14 Maret 2015).

Munir. (2009). Pembelajaran Jarak Jauh Berbasis Teknologi Informasi dan Komunikasi. Bandung. Alfabeta.

Oetomo, Budi S D. (2002). e-Education Konsep Teknologi dan Aplikasi Internet Pendidikan. Yogyakarta. Andi.

Priyanto, Dwi. (2009). Pengembangan Multimedia Pembelajaran Berbasis Komputer. Jurnal Pemikiran Alternatif Pendidikan. Purwokerto

Riduwan. (2009). Belajar Mudah Penelitian untuk Guru, Karyawan dan Peneliti Pemula. Bandung: Alfabeta

Sanaky, Hujair A, H. (2009). Media Pembelajaran. Yogyakarta: Safira Insana Press.

Sanjaya, Wina. (2010). Perencanaan dan Desain Sistem Pembelajaran. Jakarta: Kencana.

Siahaan, Sudirman. E-Learning (Pembelajaran Elektronik) Sebagai Salah Satu Alternatif Kegiatan Pembelajaran di http://www.balitbang.org. (diakses pada tanggal 14 Mei 2017).

Sugiyono. (2009). Metode Penelitian Kuantitatif, Kualitatif dan R\&D. Bandung. CV. Alfabeta.

Suhartama, I Kadek. (2010). Pengembangan Mutimedia untuk Meningkatkan

Kualitas Kembelajaran pada Mata Kuliah Media Pembelajaran, (online) jilid 46 no.3, http://pasca.undiksha.ac.id/images/img item/1181.pdf, (diakses, 14 Mei 2017)

Surjono, Harman, D. (2010). Membangun Course E-learning Berbasis Moodle. Yogyakarta. UNY Press

Thiagarajan, S, Semmel, D, S \& Semmel, M. I. (1974). Instructional Development for Training Teachers of Expectional Children.Minneapolis, Minnesota: Leadership Training Institute/Special Education, University of Minnesota.

Yamasari, Y. (2010). Pengembangan media pembelajaran Matematika Berbasis ICT yang berkualitas. Surabaya. Jurusan Matematika, FMIPA Unesa. 


\begin{tabular}{|l|l|}
\hline Nurlinah & $\begin{array}{l}\text { S.Pd. Jurusan Biologi Fakultas Matematika dan Ilmu Pengetahuan Alam, } \\
\text { Universitas Negeri Makassar. } \\
\text { Email: adik.fhyna01@gmail.com }\end{array}$ \\
\hline Adnan & $\begin{array}{l}\text { Dr., M.S., Dosen. Jurusan Biologi Fakultas Matematika dan Ilmu } \\
\text { Pengetahuan Alam, Universitas Negeri Makassar. } \\
\text { Email: adnan unm@yahoo.co.id }\end{array}$ \\
\hline Muhiddin P. & $\begin{array}{l}\text { Dr., S.Pd, M.Pd. Dosen. Jurusan Biologi Fakultas Matematika dan Ilmu } \\
\text { Pengetahuan Alam, Universitas Negeri Makassar. } \\
\text { Email: muhiddin.p@unm.ac.id }\end{array}$ \\
\hline
\end{tabular}

